BJHS: Themes 1: 13-41, 2016. C British Society for the History of Science 2016. This is an Open Access article, distributed under the terms of the Creative Commons Attribution-NonCommercialNoDerivatives licence (http://creativecommons.org/licenses/by-nc-nd/4.0/), which permits noncommercial re-use, distribution, and reproduction in any medium, provided the original work is unaltered and is properly cited. The written permission of Cambridge University Press must be obtained for commercial re-use or in order to create a derivative work.

doi:10.1017/bjt.2016.5 First published online 5 April 2016

\title{
How deep is love? The engagement with India in Joseph Needham's historiography of China
}

\author{
LEON ANTONIO ROCHA*
}

\begin{abstract}
In 2015 Dhruv Raina published Needham's Indian Network: The Search for a Home for the History of Science in India (1950-1970), bringing to light the long-range networks that institutionalized the disciplinary history of science in post-colonial India, and demonstrating the intellectual and infrastructural contributions of Joseph Needham (1900-1995) in this endeavour. This paper takes a different approach and turns to the way that Needham perceived Indian vis-à-vis Chinese civilization, and the role India played in Needham's historiography of science. It turns out that Needham's most sustained engagement with India could be found in his histories of medicine, bodily practices and alchemical traditions. In the first section of the paper, I outline the key concepts of 'Grand Titration' and 'oecumenical science' that animated Needham's historiography, which clarifies why Chinese medicine, especially acupuncture, occupies a privileged status. The second section elaborates on Needham's scholarship and vision of acupuncture, involving the verification of acupuncture's reality and efficacy via Western biomedicine. He thought acupuncture would be China's unique contribution to a new 'universal medicine' in the modern age, but by contrast Needham saw little worth refurbishing in Indian medicine, arguing via an investigation in yoga that Indian practices were generally less 'materialist' and less 'proto-scientific'. In the third section, I turn my attention to Needham's preoccupation with the history of alchemy around the world, and discuss his theorization on transmission and circulation of scientific knowledge. I comment on Needham's commitment to the thesis that European alchemy was a melting pot of Chinese, Indian, Persian, Arabic, Greek, Egyptian and Roman ideas and practices. While Needham reserved his 'deepest love' and 'profoundest desire' for Chinese civilization, India on the other hand
\end{abstract}

* Department of History, 8-14 Abercromby Square, University of Liverpool, L69 7WZ, UK. Email: leon. rocha@liverpool.ac.uk.

Rough versions of this paper were discussed at the London, Beijing and Bangalore workshops for the Intersections: New Perspectives on Science and Technology in Twentieth-Century India and China project. I thank the participants of those three occasions, especially Jahnavi Phalkey, Tong Lam, Sigrid Schmalzer and Fa-ti Fan for their insightful questions. The portions on medicine have been presented as a paper entitled 'Celestial Lancets, oecumenical science: Lu Gwei-Djen and Joseph Needham's history of acupuncture' at the Centre for East Asian Studies, Stanford University, in 2013. I thank Thomas Mullaney for the invitation, as well as Paula Findlen, Mark Edward Lewis, Robert Proctor, Londa Schiebinger and Matthew Sommer for their comments. I am grateful also for the advice from John Forrester, Dhruv Raina and Simon Schaffer at events tied to the Exploring Traditions: Sources for a Global History of Science programme at the Centre for Research in the Arts, Social Sciences and Humanities (CRASSH), University of Cambridge. For the past years I have benefited enormously from continual conversations on Joseph Needham with Gregory Blue, Francesca Bray, Christopher Cullen, Susan Daruvala, Joseph McDermott, John Moffett and Hans van de Ven. I am grateful to the two anonymous reviewers for their interventions; all mistakes and misinterpretations remain my own. 
often occupied a secondary status in his historical accounts, and in the conclusion I move from a critique of Needham's preconceptions to reflect on the writing of the history of non-Western science.

[A]fter all, the Indian civilisation, interesting though it is, is much more a part of ourselves ... There is much more in common between Indian and European civilisation, just as there is in the visible type. I often used to think when walking about the streets of Calcutta, that if the pigment was taken out of the skin of many of the people, their features would be quite similar to those of our immediate friends and relations in England. But Chinese civilisation has the overpowering beauty of the wholly other, and only the wholly other can inspire the deepest love and the profoundest desire to learn.

Joseph Needham, 'Science and society in ancient China', 1947 Conway Memorial Lecture. ${ }^{1}$

\section{Introduction: Chinese versus Indian civilizations}

In 2015 historian Dhruv Raina published a slim and elegant volume entitled Needham's Indian Network: The Search for a Home for the History of Science in India (19501970). ${ }^{2}$ Based on archival documentation as well as personal reminiscences, Raina meticulously traces the long-range networks that institutionalized the disciplinary history of science in India soon after its independence in 1947. He demonstrates that Joseph Needham (1900-1995) - the famous Cambridge biochemist, sinologist and inaugurator of the Science and Civilisation in China series (hereinafter SCC) - was a key node that connected and influenced a generation of Indian historians and philosophers. These Indian scholars include, for instance, Damodar Dharmanada (D.D.) Kosambi (19071966), Debiprasad Chattopadhyaya (1918-1993), Abdur Rahman (1923-2009), Irfan Habib (1931-) and Dhruv Raina (1958-) himself - even though Raina subsequently became highly critical of Needham's work. They sought Needham's advice on establishing academic communities and devising science policies, conversed at length with Needham in person or through decades-long correspondence, and produced scholarship that engaged deeply with the methodological and philosophical challenges arising from various volumes of SCC as well as Needham's other writings.

These Indian authors, according to Dhruv Raina, embarked on the history of science with three principal focuses in mind: '(1) understanding the place of science in society in India; (2) reflecting upon how this understanding informed the current crisis in Indian society; (3) challenging the Eurocentric conception of history'. ${ }^{3}$ On the last point in particular, Joseph Needham emerged as a constant inspiration and a frequent interlocutor. Indian scholars searched for technological achievements in ancient South Asia to

1 Joseph Needham, 'Science and society in ancient China', in Needham, The Grand Titration: Science and Society in East and West, London: Allen \& Unwin, 1969, pp. 154-176, 176.

2 Dhruv Raina, Needham's Indian Network: The Search for a Home for the History of Science in India (1950-1970), New Delhi: Yoda Press, 2015. See also the earlier paper by Dhruv Raina and S. Irfan Habib, 'The missing picture: the non-emergence of a Needhamian history of sciences in India', in Habib and Raina (eds.), Situating the History of Science: Dialogues with Joseph Needham, New Delhi: Oxford University Press, 1999, pp. 279-302, as well as Dhruv Raina, Images and Contexts: The Historiography of Science and Modernity in India, New Delhi: Oxford University Press, 2003.

3 Raina, Needham's Indian Network, op. cit. (2), p. 75. 
combat the notion that Greek civilization was the sole cradle of science (a notion that J.D. Bernal stated was driven by European 'arrogant ignorance'), and in this regard their methodology often mirrored Needham's extensive investigations into China. ${ }^{4}$ Also serving as a point of anchorage was the so-called 'Needham question'; that is, why China was overtaken by Europe in science and technology around the seventeenth century, despite China's advancement in earlier periods. Put another way, the 'Needham question' was primarily concerned with enunciating the historical conditions under which the 'Scientific Revolution' seemingly occurred in Europe, but not in China. ${ }^{5}$ Indian historians of science were addressing their analogous version of the 'Needham question': why 'modern science', or even 'capitalism' or 'modernity', did not emerge in India. This was a kind of Eurocentric anti-Eurocentrism: anti-Eurocentric in the sense of pressing for the acknowledgement of the contributions of non-Europeans to world history; Eurocentric in the sense of using Europe as a yardstick to measure those contributions. Joseph Needham, and the so-called 'visible college' of socially engaged British scientists like John Desmond (J.D.) Bernal (1901-1971), were doing the history of science because they believed historical lessons could inform contemporary debates on the planning of science for social ends, democratic participation in expert domains, and the pursuit of egalitarian politics. ${ }^{6}$ The research projects launched by Indian historians of science in the second half of the twentieth century were similarly oriented towards the present and future politics of India, additionally inflected by questions surrounding decolonization, nation building, technological transfer and the modernization of the 'Third World'.7

Dhruv Raina's reflections on the history of history of science in South Asia provide crucial insights on the connections and confrontations between science and the nation

4 John Desmond Bernal, Science in History, vol. 1: The Emergence of Science, Cambridge, MA: MIT Press, 1969 , p. 311. Sometimes the phrase 'arrogant ignorance' is misattributed to Needham, for instance in Varadaraja V. Raman, Indic Visions: In an Age of Science, Bloomington: Xlibris, 2011, p. 72.

5 I write 'seemingly' because, as Nathan Sivin has argued, a 'Scientific Revolution' may have taken place in China by the criteria that historians of science use, but did not have the social consequences that historians assume a 'Scientific Revolution' would have. Sivin argues that 'the most obvious conclusion is that those assumptions are mistaken'. See Nathan Sivin, 'Why the Scientific Revolution did not take place in China or didn't it?', Chinese Science (1982) 5, pp. 45-66. On China producing science on their own terms see Benjamin A. Elman, On Their Own Terms: Science in China, 1550-1900, Cambridge, MA: Harvard University Press, 2009. For a devastating attack on the whole 'Scientific Revolution' and China enterprise see Roger Hart, Imagined Civilisations: China, the West, and Their First Encounter, Baltimore: Johns Hopkins University Press, 2013, pp. 33-50. Moreover, it should be pointed out that Needham continually rephrased the 'Needham question' throughout his life - here I am using what may be the most 'classic' formulation. See Gregory Blue, 'Science(s), civilisation(s), historie(s): a continuing dialogue with Joseph Needham', in Habib and Raina, Situating the History of Science, op. cit. (2), pp. 29-72; H. Floris Cohen, The Scientific Revolution: A Historiographical Inquiry, Chicago: The University of Chicago Press, 1994, pp. 418-482. Chinese intellectuals contemporaneous with Needham also proposed something akin to the 'Needham question'; see Liu Dun, 'Li Yuese de shijie he shijie de Li Yuese' (Needham's World and the World's Needham), in Liu Dun and Wang Yangzong (eds.), Zhongguo kexue yu kexue geming: Li Yuese nanti ji qi xiangguan wenti yanjiu lunzhu xuan (Chinese Science and the Scientific Revolution: Selected Writings on the Needham Problem and Related Questions), Shenyang: Liaoning jiaoyu chubanshe, 2002, pp. 1-28, esp. 8-9.

6 The classic reference on the 'visible college' is Gary Werskey, The Visible College: A Collective Biography of British Scientists and Socialists of the 1930s, London: Free Association Books, 1988.

7 Raina, Needham's Indian Network, op. cit. (2), pp. 110-121. 
state in India, between scientists and historians wrestling with India's cultural heritage and plurality, and between Marxist intellectuals and other figures with a traditionalist agenda. However, not so clear in Raina's account is a very simple question: how did Joseph Needham perceive India vis-à-vis China (i.e. Needham's India as opposed to India's Needham)? Once we start looking for discussions on India in SCC and auxiliary publications, as well as the traces from documents and letters deposited at the Needham Research Institute and Cambridge University Archives, the relationship between Needham and India begins to look more ambivalent. ${ }^{8}$ The quotation heading this paper functions as a useful summary of Needham's overall outlook on India. It comes from Needham's 1947 Conway Memorial Lecture, entitled 'Science and society in ancient China', which was subsequently revised for publication in the American communist monthly Mainstream in 1960 and reprinted in Needham's famous collection of essays, The Grand Titration: Science and Society in East and West. ${ }^{9}$ For Needham, Chinese civilization was 'really the only other great body of thought of equal complexity and depth to our own [i.e. European-Semitic civilization] - at least equal, perhaps more, but certainly of equal complexity'. ${ }^{10}$ By contrast, Indian civilization was 'interesting' but apparently all too familiar: 'Our language is Indo-European, derived from Sanskrit. Our theology embodies Indian asceticism; Zeus Pater derives from Dyaus Pithar' ${ }^{11}$ Recalling his brief stay in Calcutta in 1943, just before he flew to Chongqing to take up the directorship of the Sino-British Science Co-operation Office, Needham thought that but for their skin colour the Indians were similar to the English. Therefore his 'deepest love' and 'profoundest desire' were reserved only for Chinese civilization, which in Needham's perspective was truly 'wholly other'. ${ }^{12}$ In the ranking of world civilizations, China and Europe were always already the privileged priority; India, on the other hand, occupied a secondary position.

What is the role, then, of India in Joseph Needham's historiography of science? If Needham made significant intellectual and infrastructural contributions to the development of history of science in India, for which Indian scholars felt a strong sense of camaraderie if not indebtedness, how did India, by contrast, figure in Needham's work? Irfan Habib has described in great detail Needham's explorations of the history of Indian technology, including milling, waterlifting devices, worm-gearing, the crank, the scotch-bow, the spinning wheel, liquor distillation, zinc separation and decimal notation. Habib concludes that Needham's 'statements on India, often occurring as asides, were never

8 The principal set of materials on Needham's Indian connections can be found in Papers of Joseph Needham as a Historian of Chinese Science, Technology of Medicine (Needham Research Institute, Cambridge), hereinafter 'NRI Papers'. Needham/NRI/SCC2/9/1-96. The correspondence and other items cover 1948 to 1989 .

9 Needham, op. cit. (1); Joseph Needham, Science and Society in Ancient China, Conway Memorial Lecture delivered at Conway Hall on 12 May 1947, London: Watts \& Co., 1947, available at http://conwayhall.org.uk/ memorial_lecture/science-and-society-in-ancient-china, accessed 1 July 2015; Needham, 'Science and society in ancient China', Mainstream (1960) 13, pp. 7-23, 7. On the making of this lecture and publication see NRI Papers, Needham/NRI/SCC2/364/1-14.

10 Needham, op. cit. (1), p. 176.

11 Needham, op. cit. (1), p. 176.

12 Needham, op. cit. (1), p. 176. 
carelessly made, and invariably gave a critical assessment of the existing state of research'. ${ }^{13}$ However, Joseph Needham's most sustained engagement with India could be found in his history of medicine, bodily practices and alchemical traditions, on which I concentrate in this paper. In the first section, I outline two concepts - 'grand titration' and 'oecumenical science' - that cut across Joseph Needham's corpus. I touch briefly on a minor conflict, which took place in 1950-1951, involving the datings of Indian science and Needham's accusing some of his Indian colleagues of having a 'chauvinistic tendency'. From the exploration of 'oecumenical science' it becomes clear why Chinese medicine, specifically acupuncture, has a privileged status in Needham's historiography of medicine. The following section elaborates Needham's vision of acupuncture, especially the attempts to verify acupuncture's reality and efficacy via Western biomedicine. Needham held a deep love and admiration for acupuncture because it seemed so original, peculiar and 'wholly other'; he speculated that acupuncture would eventually become China's gift to the world sometime in the twentieth or twenty-first century. One of the lengthiest discussions on India in the SCC series can be found in volume 5, Chemistry and Chemical Technology, part 5, Spagyrical Discovery and Invention: Physiological Alchemy (1983). There Needham traced the history of, as well as contemporary laboratory investigations into, yoga. Even though, in his view, yoga had great sophistication and real physiological effects, he nevertheless complained that Indian medicine and macrobiotic techniques were less 'materialist' and less 'protoscientific' compared to their Chinese equivalents. In the 1960s and 1970s, Needham was absolutely preoccupied with the history of alchemy. He was committed to the thesis that the alchemical ideas from China and India flowed into the Arab world, and then into Europe - a thesis to which contemporary historians are hostile. Below I comment on Needham's use of the work of Indo-Pakistani author Syed Mahdihassan (1892-1992), and in tandem examine Needham's ideas on the transmission and circulation of science.

In my previous publications, I have closely analysed Joseph Needham's understandings of Chinese erotic culture and 'Daoist' alchemical practices. ${ }^{14} \mathrm{My}$ aim has never been to attack Needham for 'misunderstanding' or 'misrepresenting' China or another culture (whatever those 'true' understandings or 'faithful' representations may be). My general approach is animated by the enterprise called 'sinography', which originated

13 Irfan Habib, 'Joseph Needham and the history of Indian technology', Indian Journal of History of Science (2000) 35, pp. 245-274, 245-246.

14 Leon Antonio Rocha, 'Scientia sexualis versus Ars erotica: Foucault, van Gulik, Needham', Studies in the History and Philosophy of Biology and Biomedical Sciences (2011) 42, pp. 328-343; Rocha, 'The way of sex: Joseph Needham and Jolan Chang', Studies in the History and Philosophy of Biology and Biomedical Sciences (2012) 43, pp. 611-626. I put 'Daoist' in quotation marks to highlight the fact that the Daoists were not the originators of alchemy, nor did they hold a monopoly over the practice - rather the relationship between the two was negotiated. See Fabrizio Pregadio, Great Clarity: Daoism and Alchemy in Early Mediaeval China, Stanford, CA: Stanford University Press, 2006; Nathan Sivin, 'On the word "Taoist" as a source of perplexity, with special reference to the relations of science and religion in traditional China', in Sivin, Medicine and Religion in Ancient China: Researches and Reflections, Aldershot: Variorum, 1995, pp. 303330; Sivin, 'Research on the history of Chinese alchemy', in Z.R.W.M. von Martels (ed.), Alchemy Revisited: Proceedings of the International Conference on the History of Alchemy at the University of Groningen, 17-19 April 1989, Leiden: Brill, 1990, pp. 3-20. 
from a number of scholars in the field of comparative literature and Chinese studies. To quote Eric Hayot from his Chinese Dreams: Pound, Brecht, Tel Quel, 'to read sinographically would be to abandon the attempt to force every reference of "China" into truth or falsehood, without at the same time abandoning the question of reference altogether - rather, the question of reference would have to be folded into the broader discussion of writing "China". ${ }^{15} \mathrm{My}$ intention is to dissect how assumptions concerning 'China' and 'Chinese civilization' (as well as 'the West', 'Western civilization', 'India', 'Indian civilization') impact the creation and trajectory of certain histories. Even though we encounter hypotheses and arguments from Needham and others that are no longer part of scholarly consensus, nevertheless they help current historians examine our own ideological baggage and articulate our historiographical outlooks. In this regard I am in agreement with Francesca Bray's astute remarks on the necessity of critiquing Needham's production of sinological knowledge and of using Needham as a kind of 'provocation' with which we can think through larger questions in the history of science and medicine. ${ }^{16}$

\section{From historical titration to oecumenical science}

To grasp Joseph Needham's intellectual output as a whole, I would suggest that the obligatory passage points are two interrelated, recurring metaphors found in SCC and other writings. The first is the so-called 'grand titration', and the second is 'oecumenical science'. Titration (or volumetric analysis) is one of the basic techniques in laboratory chemistry, and, to quote Needham, it is the 'determination of the quantity of a given chemical compound in a solution by observing the amount of a solution of another compound at known strength required to convert the first completely into a third, the endpoint being ascertained by a change of colour or other means'. ${ }^{17}$ To spell this out a little, suppose an analytic chemist has a beaker of clear solution containing an unknown amount of ferrous ions. To determine the concentration of ferrous ions, she could use a standardized purple solution of potassium permanganate (a 'titrant'), adding it to the beaker ('titrand') drop by drop using a burette. When the titranttitrand mixture suddenly turns deep pink in colour, that signals the end point of the process and the analytic chemist can calculate the concentration of ferrous ions via the volume of permanganate solution used. As a metaphor in Needham's history of science, the 'grand titration' involves a retrospective competition between China and Europe, with Needham acting as the chemist-cum-historian 'fixing' the dates of the discovery of whatever scientific theory or invention of whichever technology. In principle, either European science or Chinese science might act as the 'titrant' (a 'standard solution'

15 Eric Hayot, Chinese Dreams: Pound, Brecht, Tel Quel, Minneapolis: University of Minnesota Press, 2004, p. 185. More generally see Eric Hayot, Haun Saussy and Stephen G. Yao (eds.), Sinographies: Writing China, Minneapolis: University of Minnesota Press, 2008; Haun Saussy, Great Walls of Discourse and Other Adventures in Cultural China, Cambridge, MA: Harvard University Press, 2001.

16 Francesca Bray, 'How blind is love? Simon Winchester's The Man Who Loved China', Technology and Culture (2010) 51, pp. 578-588.

17 Joseph Needham, 'Introduction', in Needham, The Grand Titration, op. cit. (1), pp. 11-13, 12. 
containing a known molarity of 'science'), and then China or Europe might be the 'titrand' to be analysed for the amount of 'science' it contains. In addition, the Chinese and European civilizations are 'pitted against one another' in order to discern their various social, political or intellectual constituents to 'see why one combination could far excel in mediaeval times while another could catch up later on and bring modern science itself into existence' - another way of expressing the so-called 'Needham question'. ${ }^{18}$

As history of science as a discipline was being domesticated in India in the early 1950s, scholars were similarly trying to fix the dates of scientific discoveries and technological innovations in India. Needham and these scholars, who were mostly professional-scientist-turned-historians, came to loggerheads in what Dhruv Raina called an 'embarrassing controversy' ${ }^{19}$ In November 1950, a symposium took place at the University of Delhi, co-organized by the National Institute of Sciences of India (predecessor of the Indian National Science Academy or INSA) and UNESCO's Science-Cooperation Office for South Asia. ${ }^{20}$ Needham planned to attend this meeting but cancelled in summer 1950 due to the ill health of his spouse Dorothy Moyle Needham (1896-1987). Alexander Wolsky (1902-2004), the principal officer at UNESCO's South Asia office, arranged for Needham to receive copies of the papers presented at the Delhi symposium. Needham then wrote a review of the Delhi symposium for Nature, published in the 14 July 1951 issue. ${ }^{21} \mathrm{He}$ began the review by pointing out that the fixing of dates of texts and artefacts for the history of science in India was extremely difficult. While he praised several papers for being 'judicious and careful' with datings, he stated that unfortunately this could not be said 'of the majority of the papers which put forward quite unacceptably early datings' ${ }^{22}$ Several papers especially offended Needham: the paper on astronomy by Kripa Shankar Shukla and K.R. Dixit seemed to maintain 'that the Babylonians owed the sexagesimal division of the circle and the system of twenty-eight lunar mansions to India'; the paper by Priyada Ranjan Ray waxed lyrical on the achievements of the potters of the Mohenjo-Daro civilization ( $c$. twenty-sixth to nineteenth centuries BCE) but 'no comparison [was] made with other pottery products'; Sunder Lal Hora's presentation 'read too much into ancient texts, as when the Pillar Edicts of Asoka or the text of the "Arthashastra" [were] appealed to as evidence for advanced fishery legislation'. One of the most objectionable claims, in Needham's opinion, was to be found in Prabodh Chandra Bagchi's contribution, in which Bagchi claimed 'Indian influence on a [Chinese] mathematical work such as "Sun Tzu Suan Ching" (third century CE) on the ground that the [Chinese] word "Ching" [was] afterwards used for translating the term "Sutra" in Buddhist texts'.23

18 Needham, op. cit. (17), p.12.

19 Raina, Needham's Indian Network, op. cit. (2), pp. 53-69.

20 Materials associated with the 1951 Delhi symposium are contained in NRI Papers, Needham/NRI/SCC2/ $9 / 7$.

21 Joseph Needham, 'History of science and technology in India and South-East Asia', Nature (1951) 168, pp. 64-65.

22 Needham, op. cit. (21), p. 64.

23 Needham, op. cit. (21), p. 64. 
Overall, Joseph Needham chastised the 'chauvinistic tendency' in all the papers, and he observed an 'effort to minimise foreign influences on Indian science and to emphasise all outward transmissions'. ${ }^{24}$ Quoting extensively from the preface to La doctrine classique de la médecine indienne (1949) by French indologist Jean Filliozat (1906-1982), Needham suggested that the Indian scholars were 'moved by national pride' and thus 'prone to maintain that their sciences in high antiquity surpassed even those of today'. ${ }^{25}$ The ichthyologist Sunder Lal Hora (1896-1955), president of the National Institute of Sciences of India, was disappointed with Needham's critical review and penned a strongly worded response, also published in Nature. ${ }^{26}$ Hora by and large ignored Needham's historiographical criticisms, focusing instead on Needham's lack of acknowledgement of the role of the National Institute of Sciences of India in organizing the Delhi symposium and thus giving the 'erroneous impression that it was the work of the UNESCO Science Co-Operation Office for South Asia'. ${ }^{27}$ Hora also stated that a 'Chronology Committee', consisting of 'historians and scientific men', was being set up to address Needham's concerns regarding datings. ${ }^{28}$ Dhruv Raina points to the clash between the Indian scholars' agenda and Joseph Needham's vision. For the Indian scholars, 'it was a question of recreating a glorious image of the past of Indian science in order to legitimise their own activity and ensure government support for science'. ${ }^{29}$ For Needham, on the other hand, the careful fixing of the dates of major discoveries and inventions and the accumulation of chronologies (the process which he had named 'grand titration' by the 1960s) was not to write a nationalistic history of science, but to provide a general cultural history of humankind and an account of 'oecumenical science' to which all civilizations contributed. ${ }^{30}$ Of course, there is a deep irony here because, as Francesca Bray argues, Needham was certainly not immune to triumphalism - proudly proclaiming that the Chinese discovered a certain idea or invented a particular technology centuries before the Europeans which dovetailed a nationalistic reception and appropriation of SCC in China that Needham never really sought to correct. ${ }^{31}$

The second key idea that allows us to penetrate Needham's vast corpus is the 'oecumenical'. This is best illustrated by, on first sight, a somewhat baffling diagram that Needham devised in 1966 for his paper 'The roles of Europe and China in the evolution of oecumenical science', which was an address at the opening of the exhibition on Chinese medicine at the Wellcome Collection in London as well as the presidential speech for the British Association for the Advancement of

24 Needham, op. cit. (21), p. 64.

25 Needham, op. cit. (21), p. 64.

26 S.L. Hora, 'History of science and technology in India and South-East Asia', Nature 168 (1951), pp. 1047-1048.

27 Hora, op. cit. (26), p. 1047.

28 Hora, op. cit. (26), p. 1048.

29 Raina, Needham's Indian Network, op. cit. (2), p. 62.

30 Raina, Needham's Indian Network, op. cit. (2), p. 61.

31 Bray, op. cit. (16), p. 588. Floris Cohen would go further and claim that Needham was guilty of 'consistent aggrandisement': Cohen, op. cit. (5), p. 437. 


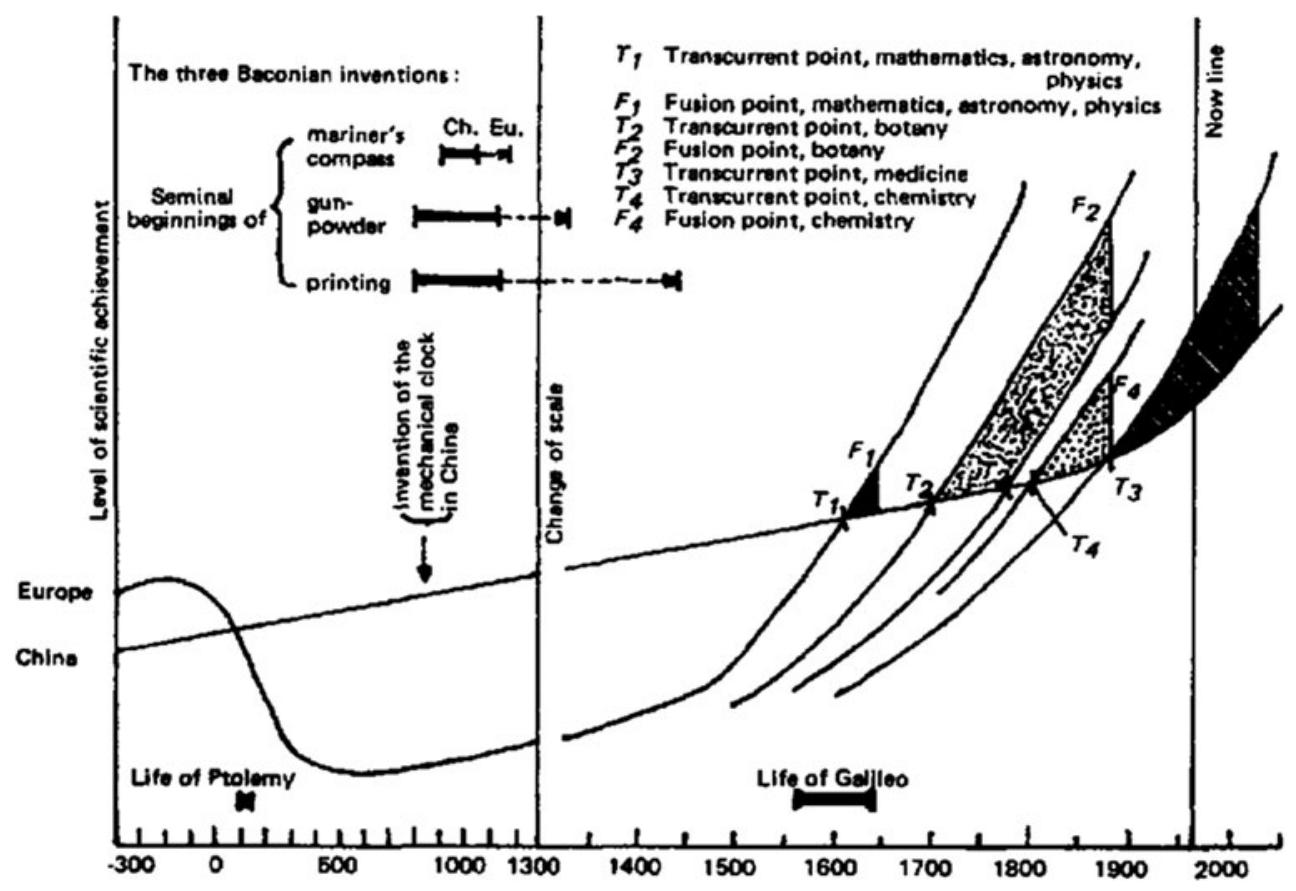

Figure 1. From Joseph Needham, 'The roles of Europe and China in the evolution of oecumenical science', in Needham, Clerks and Craftsmen in China and in the West, Cambridge: Cambridge University Press, 1970; first published 1966, p. 414.

Science. ${ }^{32}$ In Figure 1, time is on the $x$ axis and 'level of scientific achievement' is on the $y$ axis. ${ }^{33}$ The top line is 'Europe' and the bottom line is 'China'. Following those two lines, Needham was essentially suggesting that science in the Graeco-Roman world, up to around $100 \mathrm{CE}$ and during Ptolemy's lifetime (c.90-c.168 CE), was more advanced than in China before the first half of the Eastern Han Dynasty (25-220 CE). The level of scientific achievement then dipped dramatically in Europe during the 'Dark Ages', while Chinese science grew steadily. From the seventeenth century onwards, Western science developed exponentially, and in Needham's view it finally overtook China around 1600 during Galileo's lifetime (1564-1642). The point at which Western mathematics, astronomy and physics overtook their Chinese counterparts was represented by $T_{1}$ : Needham called this the 'transcurrent point'. Further along, there is another point marked $F_{1}$. This was the 'fusion point', when Western and Chinese mathematics,

32 Joseph Needham, 'The roles of Europe and China in the evolution of oecumenical science', in Needham, Clerks and Craftsmen in China and in the West: Lectures and Addresses on the History of Science and Technology, Cambridge: Cambridge University Press, 1970; first published 1966, pp. 396-418. Reprinted in Kenneth Girdwood Robinson (ed.), Science and Civilisation in China, vol. 7: The Social Background, part 2: General Conclusions and Reflections, with contributions by Ray Huang and an introduction by Mark Elvin, Cambridge: Cambridge University Press, 2004, pp. 24-43.

33 See also analysis in Cohen, op. cit. (5), pp. 467-470. 
astronomy and physics supposedly merged to become one single, universal or 'oecumenical' science. According to Needham, 'By +1644 , the end of the Ming Dynasty, there was no longer any perceptible difference between the mathematics, astronomy and physics of China and Europe; they had completed fused, they had coalesced'. ${ }^{34}$ The reason behind this is that 'by a historical coincidence the rise of modern science in Europe was closely accompanied by the activities of the Jesuit mission in China (Matteo Ricci S.J. (Li Ma-Tou) died in Peking in +1610 )' ${ }^{35}$ Needham supplemented his argument with the famous 'rivers' metaphor: 'one can well consider the older streams of science in the different civilisations like rivers flowing into the ocean of modern science'. ${ }^{36}$

There is no space here to open a lengthy debate on Joseph Needham's historiography of astronomy. Suffice it to say that a number of historians have attacked his claim along several lines: whether the paltry evidence on a limited group of elite Chinese scholarofficials who might have appropriated parts of European astronomy amounted to a syncretism of two Chinese traditions (H. Floris Cohen); whether the Jesuit missionaries actually represented European astronomy accurately as they disseminated the Tychonic system but withheld Copernicanism from the Chinese (Nathan Sivin); whether the metaphor of 'fusion' into an 'oecumenical' astronomy makes sense at all (Roger Hart). ${ }^{37}$ I would, however, like to draw attention to $T_{3}$, the 'transcurrent point' for medicine. In Needham's scheme, Western medicine lagged significantly behind Chinese medicine in the seventeenth century, but emerged victorious after the nineteenth century and particularly into the twentieth. He lists the innovations in Western medicine: clinical discoveries (Morgagni, Auenbrugger, Corvisart, Laënnec), pharmaceutical chemistry (Pelletier, Caventou), neurophysiology (Bell, Magendie), bacteriology (Pasteur), immunology (Jenner), antiseptics and anaesthesia (Lister), radiology (Röntgen), radiotherapy (Curie) and radioisotopes (Joliot-Curie), parasitology and discovery of malaria plasmodium (Laveran, Ross), vitamins (Hopkins), sulpha-drugs (Domagk), antibiotics and so on. ${ }^{38}$ But using therapeutic success rather than diagnostic understanding, Needham placed $T_{3}$ at the year 1900, arguing that 'a patient may not have been much better off in Europe than in China before the beginning of the twentieth century'. ${ }^{39}$ Note that there is no 'fusion point' (or $F_{3}$ ) for medicine in Needham's diagram. For him, 'fusion' had already taken place in the fields of astronomy, mathematics, physics, botany and chemistry, but the 'fusion' between Western and Chinese medicine had not yet happened. Needham's explanation is worth quoting at length here:

I dare say this is the case because, although physicists don't quite like you to say so, and astronomers equally may demur, nevertheless the phenomena of these sciences are surely much simpler than those with which biologists have to deal, and a fortiori physiologists, pathologists and medical men. Wherever the living cell is concerned, and a fortiori the living cell in its

34 Needham, op. cit. (32), p. 398.

35 Needham, op. cit. (32), p. 397.

36 Needham, op. cit. (32), p. 397.

37 Cohen, op. cit. (5), pp. 469-470; Sivin, op. cit. (5); Hart, op. cit. (5), pp. 33-50.

38 Needham, op. cit. (32), pp. 406-407.

39 Needham, op. cit. (32), p. 407. 
metazoan forms of high organisation, the puzzles are profounder, the tools both practical and conceptual more inadequate, the room for doubt greater. However optimistic one may feel as a young biologist or biochemist, the secret of life is still not yet just round the next bend. I speak from experience. Thus the coming together of the two cultural traditions, the fusion of them into a unitary modern medical science, has not even now been effected. Many people, of course, when they think of Chinese medicine today, imagine it as some kind of 'folk-medicine', something bizarre and quite outdated, some sort of meaningless curiosity, but in truth these are all entirely wrong ways of reacting to it ... While conserving a mediaeval body of theory, it contains a wealth of empirical experience which has got to be taken account of ... However, the rationale of some of the most important Chinese therapeutic practices, such as acupuncture ... is not yet clearly understood; and obviously not all the drugs of the very rich traditional Chinese pharmacopoeia have yet been thoroughly examined from the biochemical and pharmacological point of view. ${ }^{40}$

From this Joseph Needham tentatively put forward a 'law of oecumenogenesis', whereby 'the more organic the subject-matter of a science, the higher the integrative level of the phenomena with which it deals, the longer will be the interval elapsing between the transcurrent point and the fusion point, as between Europe and an Asian civilisation'. ${ }^{41}$ Medicine, then, occupies a special status in Needham's historiography, and as I have argued elsewhere, his 'grand titration' morphs into something akin to another chemical process, 'distillation'. ${ }^{42}$ If we again return to the diagram of 'oecumenical science', and examine the top left-hand corner, Needham included the 'three Baconian inventions', a reference to the passage in Novum Organum Scientiarum (1620) in which Francis Bacon (1561-1626) pointed towards 'the art of printing, gunpowder and the nautical compass' as 'three things [that] have changed the face and condition of things all over the globe ... so that no empire or sect or star seems to have exercised a greater power and influence on human affairs than those mechanical things' ${ }^{43}$ Joseph Needham argued that the Chinese had come up with all three inventions before Europeans, by centuries. ${ }^{44}$ But arguing that there were Chinese precedents with printing, and 'giving China the credit where it is due', were in no way suggesting that we ought to combine European and Chinese printing, to manufacture all of our

40 Needham, op. cit. (32), pp. 401-402.

41 Needham, op. cit. (32), p. 415.

42 Rocha, 'The way of sex', op. cit. (14), pp. 622-623.

43 Francis Bacon, The New Organon (1620) (ed. Lisa Jardine and Michael Silverthorne), Cambridge: Cambridge University Press, 2000, p. 100.

44 Needham was by no means the first to argue this. In fact, the idea that the Chinese invented gunpowder and print (but not the compass) 'thousands of years' before the Europeans could be traced back to Montaigne's 'Des Coches' (1588). See David A. Bourchoff, 'The three great inventions of modern times: an idea and its public', in Klaus Hock and Gesa Mackenthun (eds.), Entangled Knowledge: Scientific Discourses and Cultural Difference, Münster: Waxmann Verlag, 2012, pp. 133-164. The idea of the 'three Baconian inventions' spread to China in the late nineteenth and early twentieth centuries via Protestant missionaries and Western sinologists/orientalists, which was then transformed by Chinese intellectuals such as Xiang Da (1900-1966) into the story of the 'four great inventions' (si da faming) of ancient China, i.e. the Chinese came up with gunpowder, compass, printing and papermaking centuries, if not millennia, before the Europeans. Joseph Needham then popularized the story of the 'four great inventions' in the mid-twentieth century. See Iwo Amelung, 'Historiography of science and technology in China: the first phase', in Jing Tsu and Benjamin A. Elman (eds.), Science and Technology in Modern China, 1880s-1940s, Leiden: Brill, 2013, pp. 39-66, esp. 46-52. 
books in the present day. Nor did Needham argue that we would need to revive Chinese astronomy, physics, mathematics, botany and chemistry, because the 'fusion' between Chinese and European traditions in these knowledge domains had already taken place. Those scientific fields had settled and doing their histories would just be a matter of credit attribution via 'grand titration'. But with Chinese medicine, Needham was convinced that there was something to be recovered and effectively distilled, the 'wealth of empirical evidence' and 'therapeutic practices such as acupuncture' that could be fused with Western medicine to create a genuinely 'oecumenical medicine which [would] combine all the true powers discovered both in China and Europe, a medicine still in statu nascendi'. ${ }^{45}$ To anticipate myself a little, Needham was supportive of the so-called programmes for the 'integration of Chinese and Western medicines' (zhongxiyi jiehe) in the People's Republic of China that began in the $1960 \mathrm{s.}{ }^{46}$ Needham held a special, deep love for acupuncture, something which seemed so 'otherly' and unfamiliar and splendorous. He firmly believed that acupuncture would be something uniquely Chinese that could benefit all humankind.

\section{From electrified needles to yogi ECGs}

Joseph Needham never actually published a Science and Civilisation volume on Chinese medicine during his lifetime. Volume 6, part 6, on Chinese medicine was released posthumously in the year 2000 and included sections written by Lu Gwei-Djen (1904-1991) and Needham, edited by Nathan Sivin. ${ }^{47}$ Needham was already deeply fascinated by the history of Chinese medicine in the 1940s when he was in Chongqing and Kunming. As Vivienne Lo has discovered, Lu Gwei-Djen, Needham's lifelong collaborator and his second wife, was also a major influence on Needham's thinking on Chinese medicine. Lu's father was a 'progressive pharmacist trained in the dispensing of modern Western medicine as well as the materia medica of ancient China', and Lu herself was trained in the Rockefeller-funded Peking Union Medical College before pursuing doctoral research at the University of Cambridge, under Needham's first wife, the biochemist Dorothy Moyle Needham. ${ }^{48}$ Joseph Needham intensified his collection of materials on

45 Needham, op. cit. (32), pp. 401-402; Lu Gwei-Djen and Joseph Needham, 'Authors' foreword', in Lu and Needham, Celestial Lancets: A History and Rationale of Acupuncture and Moxa, reprint edn, London: Routledge, 2005; first published 1980, pp. xix-xxi, xx.

46 On the programme of 'integration of Chinese and Western medicine' see Kim Taylor, Chinese Medicine in Early Communist China, 1945-1963: A Medicine of Revolution, New York: RoutledgeCurzon, 2005, pp. 109-150, esp. 135-137; Volker Scheid, Chinese Medicine in Contemporary China: Plurality and Synthesis, Durham, NC: Duke University Press, 2002; Scheid, 'The People's Republic of China', in T.J. Hinrichs and Linda L. Barnes (eds.), Chinese Medicine and Healing: An Illustrated History, Cambridge, MA: The Belknap Press of Harvard University Press, 2013, pp. 239-283.

47 Joseph Needham and Lu Gwei-Djen, Science and Civilisation in China, vol. 6: Biology and Biological Technology, part 6: Medicine (ed. Nathan Sivin), Cambridge: Cambridge University Press, 2000.

48 Vivienne Lo, 'Introduction: survey of research into the history and rationale of acupuncture and moxa since 1980', in Lu and Needham, op. cit. (45), pp. xxv-li, xxv. One important caveat regarding the discussion below on medicine and acupuncture, particularly Lu Gwei-Djen and Joseph Needham's book Celestial Lancets: even though scholars in the history of Chinese science, particularly those who have worked closely with Lu and Needham, are acutely aware of Lu's great influence on Needham and her 
Chinese medicine after Mao Zedong declared, in 1958, that Chinese medicine was a 'treasure-house'. ${ }^{49}$ After the publication of the first and second volumes of SCC (in 1953 and 1956 respectively), Needham emerged as one of the major nodes in the global network for Chinese medicine. His expertise in biochemistry and Chinese history, and his status as a fellow of the Royal Society and a Cambridge don, meant that he began to be inundated with questions on Chinese medicine from scientific experts and laypersons alike. ${ }^{50}$ Acting as a referee and arbiter of both historical and scientific literature, as well as simply having large numbers of scholars sending in books and offprints for his perusal, Needham became immersed in the realm of research on the verification of Chinese medicine via Western biomedicine emerging from sinophone areas, Europe and the United States.

Yet, despite his long engagement with Chinese medicine, Needham repeatedly delayed the writing of the medicine volume. He tried to persuade Nathan Sivin to write this volume, but Sivin declined. ${ }^{51}$ The fundamental historiographical background to Needham's hesitation was precisely this vision of 'ecumenism' and 'fusion' of Western and Chinese medicine. Needham and Lu Gwei-Djen eagerly awaited research that assessed the 'therapeutic achievements of traditional medicine by the standards of modern science', particularly research on the reality and efficacy of acupuncture, to come to fruition. ${ }^{52}$ There were, broadly speaking, three strands of research on acupuncture that Lu and Needham monitored: the materiality of the so-called system of 'meridians' (jingluo) and 'acupoints', the electrification of acupuncture to enhance its effects, and the geography of pain on the human body. ${ }^{53}$ They consulted scientific experts in person or in lengthy correspondence; accounts of personal experiences with acupuncture and anecdotal evidence were collected, combined with details on visits to clinics, laboratories, operation theatres and museums across China in 1958, 1964 and 1972.54

contributions to SCC, it has not so far been possible to delineate exactly which lines of inquiry or turns of argumentation belonged to $\mathrm{Lu}$ and which to Needham. It is worth mentioning that Celestial Lancets is explicitly billed as 'authored by Lu Gwei-Djen and Joseph Needham', in contrast to volumes of SCC which are often labelled 'Joseph Needham in collaboration with Lu Gwei-Djen'. Since the Lu papers remain closed to the public, the question of Lu's versus Needham's authorship cannot be adequately addressed.

49 Taylor, op. cit. (46), pp. 120-121.

50 For instance, NRI Papers, Needham/NRI2/SCC2/315/1-220, contains correspondence regarding Chinese medicine (including journal refereeing) dating from 1951 to 1991; Needham/NRI2/SCC2/284/2/1-57 contains Needham's activities related to the British Medical Acupuncture Society, as well as letters from non-academics seeking Needham's advice on acupuncture treatment, dating from 1946 to 1994.

51 Nathan Sivin, 'Editor's introduction', in Needham and Lu, op. cit. (47), pp. 1-37, 1-3.

52 Needham and Lu, op. cit. (47), p. 66.

53 See the chapter entitled 'Therapy and analgesia: physiological interpretations' in Lu and Needham, op. cit. (45), pp. 184-261; Lo, 'Introduction', in Lu and Needham, op. cit. (45), pp. xlii-xlix.

$54 \mathrm{Lu}$ and Needham, op. cit. (45), pp. 184-261, contains references throughout to the three tours of China. NRI Papers, Needham/NRI2/5/1/1-7 (Joseph Needham's notebooks from his 1958 tour of China) and specifically Needham/NRI2/5/1/4 contain notes of visits to the Chinese Medical Research Institute in Beijing, the Historical Medical Museum in Shanghai, and Sichuan Medical School, among others. Needham/NRI2/ 5/2/1-9 (documents arising from Joseph Needham's 1964 tour of China and Japan), specifically Needham/ NRI2/5/2/4, contain notes on the Chinese Traditional Medicine Hospital in Shenyang, the Shanghai School of Traditional Chinese Medicine, and Zhongshan Hospital in Shanghai, among others. Needham/NRI2/5/4/ 1-4 (Joseph Needham's notebooks from his trip to China in 1972), specifically Needham/NRI2/5/4/2, 
Investigations on the reality of 'meridians' involved histological studies in the 1950s1960s on a 'third circulatory network' that supposedly coexisted with the vascular and lymphatic systems. ${ }^{55}$ By the mid-1960s, electrical currents had become the privileged method to investigate the 'reality' of acupuncture by measuring subcutaneous tissue conductivity and resistance phenomena; electrical currents were also tested as a means to amplify acupuncture's analgesic and therapeutic effects. The electrical programme was a thoroughly transnational enterprise, involving universities and clinics in Western Europe, North America, China and Japan. ${ }^{56}$

In 1958, Lu Gwei-Djen and Needham visited the No. 4 People's Hospital in Xi'an and witnessed first-hand experiments on electroacupuncture. ${ }^{57}$ The needles were connected to an electrical machine that caused intermittent twitching of the muscles and stimulation of nerve endings. The Chinese acupuncture programme absorbed new research conducted in Europe and America on 'visceral pain' - the disorder of certain internal organs could lead to the emergence of certain 'trigger points' or 'sensitive zones' distributed on the surface of the body. ${ }^{58}$ This included experimental work conducted by physicians in New York and Vancouver and, most significantly, Ronald Melzack (1929-) at McGill University. ${ }^{59}$ Melzack and Patrick David Wall (1925-2001) at MIT proposed the 'gate theory of pain' in 1965, essentially a cybernetic model of the central nervous system that conceived the brain, spinal cord and nerves as a vast network of gates and feedback loops. ${ }^{60}$ It was theorized that the placement of a whole series of needles on different parts of the body, combined with electrical stimulation, could achieve an analgesic effect by 'overloading' or 'congesting' junctions within a gigantic network of neural circuits. ${ }^{61}$ Unlike histological and physiological theories, the gate theory of pain was

contain notes on Northwest Medical School in Xi'an, the Chinese Traditional Medicine Hospital in Beijing, and the Chinese Traditional Medicine Hospital in Nanjing, among others.

$55 \mathrm{Lu}$ and Needham, op. cit. (45), pp. 185-186.

$56 \mathrm{Lu}$ and Needham, op. cit. (45), pp. 187-194.

$57 \mathrm{Lu}$ and Needham, op. cit. (45), pp. 188, 190.

$58 \mathrm{Lu}$ and Needham, op. cit. (45), pp. 204-213.

$59 \mathrm{Lu}$ and Needham, op. cit. (45), pp. 233-235. Joseph Needham met Ronald Melzack and his colleagues at McGill University to discuss acupuncture, pain and electrical stimulation in summer 1975: NRI Papers, Needham/NRI2/SCC2/290/43, Needham/NRI2/SCC2/285/3/16 and Needham/NRI2/SCC2/290/50. He also planned to meet neurologist Wilder Penfield (1891-1976) to discuss brain localization and acupuncture in that same trip to Montreal, but it is unclear if this meeting ever materialized: NRI Papers, Needham/NRI2/ SCC2/290/42; he met Patrick Wall, who at that point was a professor at University College London, in 1974: NRI Papers, Needham/NRI2/SCC2/285/1/14.

60 Ronald Melzack and Patrick D. Wall, 'Pain mechanisms: a new theory', Science (1965) 150, pp. 971979; Ronald Melzack, The Puzzle of Pain, New York: Basic Books, 1973. Needham read Melzack’s book with enthusiasm: NRI Papers, Needham/NRI2/SCC2/285/3/21.

61 For Melzack's papers on acupuncture see Ronald Melzack, 'How acupuncture can block pain', Impact of Science on Society (UNESCO) (1973) 23, pp. 65-75; Ronald Melzack and M.E. Jeans, 'Acupuncture analgesia: a psychophysiological explanation', Minnesota Medicine (1974) 57, pp. 161-166; Ronald Melzack, 'Acupuncture and pain mechanisms', Der Anaesthesist (1976) 25, pp. 204-207; Elisabeth J. Fox and Ronald Melzack, 'Transcutaneous electrical stimulation and acupuncture: comparison of treatment of lowback pain', Pain (1976) 2, pp. 141-148; Ronald Melzack, Dorothy M. Stillwell and Elisabeth J. Fox, 'Trigger points and acupuncture points for pain: correlations and implications', Pain (1977) 3, pp. 3-23; Ronald Melzack, 'Myofascial trigger points: relation to acupuncture and mechanisms of pain', Archives of Physical Medicine and Rehabilitation (1981) 62, pp. 114-117; Ronald Melzack and Patrick D. Wall, 
agnostic with regard to the 'real' existence of the meridians or acupoints. 'Trigger zones' on the body could be determined simply via patient testimony and clinical observation. Nor did the gate theory require the adoption of the cosmology ( $q i$, 'Five Elements' or systematic correspondences) from Chinese medicine, a cosmology that Joseph Needham argued was medieval in character (comparable to Aristotle and Galen) and that had inhibited the development of Chinese science (and thus could be safely discarded). ${ }^{62}$ At the same time Needham and Lu followed the Communist Party-endorsed 'acupuncture anaesthesia' (zhenchi mazui) project in China with great excitement; this opened the possibility of performing operations with acupuncture and without conventional forms of chemical anaesthetic. ${ }^{63}$ The Chinese state was at once invested in demonstrating the cultural superiority of China through a manual, folk technique of acupuncture, and simultaneously 'scientizing' acupuncture through Western neuroscientific and biomedical investigations under the banner of 'integration of Chinese and Western medicines' (zhongxiyi jiehe). ${ }^{64}$ As Volker Scheid and Kim Taylor have argued, this 'integration' was a deeply ambivalent programme because, essentially, it sought to explain the best

'Acupuncture and transcutaneous electrical nerve stimulation', Postgraduate Medical Journal (1984) 60, pp. 893-896; Ronald Melzack and Patrick D. Wall, 'Acupuncture and transcutaneous electrical nerve stimulation', Acupuncture in Medicine (1986) 3, pp. 8-10.

62 As Needham has mentioned on a vast number of occasions, but for a summary of his view on traditional Chinese medical theory see Needham and Lu, op. cit. (47), pp. 65-66. Limited space here will not allow me to elaborate this in detail, but essentially Needham's view was that traditional Chinese medicine consisted of an accumulated body of empirical, experiential knowledge. Unfortunately, the 'problem' began with the crystallization or even fossilization of that knowledge in correlative (or analogical) thinking (i.e. a highly elaborate set of systematic correspondences, yin-yang and 'Five Elements' schemes, 'Liver is Wood, Heart is Fire' and so on), which permeated all spheres of intellectual inquiry in early China. For Needham the only 'mature' kind of scientific reasoning is causative ( $A$ causes $B$ causes $C$ ) and Chinese medicine never made that transition from 'proto-scientific' correlative to 'modern scientific' causative thinking, and the culprit was none other than Confucianism. The Confucians retarded the development of science because they were always preoccupied with the precise arrangement of human affairs (in contrast to the Daoists who supposedly were genuinely interested in the observation of nature). Put another way, the Confucians were only interested in the observation of nature insofar as natural phenomena could be mobilized to legitimize social hierarchies and political power, and they did that by ruthlessly trimming and bashing observations into systematic correspondences, and so empirical science was radically wrecked and derailed by social interest. This view could also be detected in the work of sinologist Angus Charles Graham (1919-1991); see A.C. Graham, Disputers of the Tao: Philosophical Argument in Ancient China, La Salle, IL: Open Court, 1989. Even historian of medicine Paul Unschuld would write, 'The conceptual framework of systematic correspondences ... was nothing more than a complex labyrinth, in which those thinkers seeking solutions to medical questions wandered aimlessly in all directions, lacking any orientation, and unable to find a feasible way out. Such a solution came only with the collapse of the Confucian social order and the subsequent weakening of the worldview that had prevailed for centuries'. See Paul Unschuld, Medicine in China: A History of Ideas, Berkeley: University of California Press, 1985, p. 197. For a deconstruction of 'correlative thinking' see Hart, op. cit. (5), pp. 111-113. The Bengali Marxist philosopher and historian Debiprasad Chattopadhyahya has appropriated Needham's line of argument to claim that materialist, empirical, rational, naturalist, atheistic medicine in ancient India was likewise wrecked and derailed by idealist, theistic, conservative Vedic Hinduism to reinforce the caste system. See Raina, Needham's Indian Network, op. cit. (2), pp. 94-101; Debiprasad Chattopadhyahya, Science and Society in Ancient India, Calcutta: Research India Publications, 1977; Chattopadhyahya, Lokayata: A Study in Ancient Indian Materialism, New Delhi: People's Publishing House, 1959.

63 Lu and Needham, op. cit. (47), pp. 218-230.

64 Taylor, op. cit. (46), pp. 137-144. 
theories and practices in Chinese medicine via Western science (the 'treasure' in Mao Zedong's slogan 'Chinese medicine is a treasure-house'), and at the same time disregarding the dross. In other words this was not a symmetrical arrangement; it was not two medical systems of equal epistemological status unifying. ${ }^{65}$ But for Joseph Needham this constituted the 'fusion' of the best of East and West, and the creation of an 'oecumenical medicine' in action.

In the 1970s Lu Gwei-Djen and Joseph Needham believed that they could no longer wait until the global network of researchers on acupuncture came up with definitive proofs, confident as they were that the 'scientific rationale of acupuncture [would] in due course be established'. ${ }^{66}$ They moved ahead and published Celestial Lancets: A History and Rationale of Acupuncture and Moxa in 1980, separate from the SCC series. Although Lu and Needham did not spell out precisely what precipitated their decision to intervene with their vision of Chinese medicine, we could speculate that a number of events in the 1970s, which generated an 'acupuncture fever' in the West, might have spurred them to action: James Reston's report on acupuncture in the New York Times which introduced Chinese medicine to the American public, ${ }^{67}$ or the trial of acupuncturist Miriam Lee (1926-2009) in California in 1974 and the subsequent legalization of acupuncture in the state in $1976 .{ }^{68}$ In Celestial Lancets, Lu and Needham did something unprecedented in their writings. Chapter 5 of that book, entitled 'Therapy and analgesia: physiological interpretations', explicitly discussed scientific evidence for acupuncture and projected a hopeful future. Perhaps acupuncture would eventually be explained via 'trigger events in the hypothalamus which activate the pituitary gland and lead to an increase of cortisone production by the suprarenal cortex'. Perhaps it would be explained via stimulation of 'the autonomic nervous system in such a way as to lead to an increased output of antibodies from the reticulo-endothelial system'. Perhaps it would be explained via 'afferent input junctions in thalamus, medulla or cord in such a way as to prevent all pain impulses getting through to the cortex regions of the brain'. ${ }^{69}$

The general trajectory of Chinese medicine in the 1980s and 1990s turned out quite differently from what $\mathrm{Lu}$ and Needham predicted. ${ }^{70}$ The definitive proof on

65 Taylor, op. cit. (46), pp. 135-137; Scheid, Chinese Medicine in Contemporary China, op. cit. (46), pp. 65-106.

$66 \mathrm{Lu}$ and Needham, op. cit. (45), p. 6.

67 James Reston, 'Now, about my operation in Peking', New York Times, 26 July 1971, p. 1; Mei Zhan, Other-Worldly: Making Chinese Medicine through Transnational Frames, Durham, NC: Duke University Press, 2009, p. 15; Candy Brown, The Healing Gods: Complementary and Alternative Medicine in Christian America, New York: Oxford University Press, 2013, pp. 143-148.

68 Miriam Lee, Insights of a Senior Acupuncturist: One Combination of Points Can Treat Many Diseases, Boulder: Blue Poppy Press, 1992; Zhan, op. cit. (67), pp. 80-81. More generally, Linda L. Barnes, 'A world of Chinese medicine and healing: part one', in T.J. Hinrichs and Linda L. Barnes (eds.), Chinese Medicine and Healing: An Illustrated History, Cambridge, MA: Harvard University Press, 2013, pp. 284-333.

$69 \mathrm{Lu}$ and Needham, op. cit. (45), p. 6.

70 Elisabeth Hsu, 'The history of Chinese medicine in the People's Republic of China and its globalization', East Asian Science, Technology and Society: An International Journal (2008) 2, pp. 465-484; Volker Scheid, 'Globalizing Chinese medical understandings of menopause', East Asian Science, Technology and Society: An International Journal (2008) 2, pp. 485-506; more generally see Volker Scheid and Hugh MacPherson (eds.), Integrating East Asian Medicine into Contemporary Healthcare, London: Churchill Livingstone, 2011. 
acupuncture's efficacy had not arrived; investigations into the extraction of active ingredients from Chinese herbs and the search for potentially lucrative pharmaceuticals began to receive far more attention compared to the verification of the materiality of meridians or the amplification of acupuncture using electrical machines. Acupuncture anaesthesia, especially its sensational use in open-heart or open-lung surgery on fully conscious patients, was discredited as a propaganda exercise and a symptom of the Cultural Revolution's excess, and silently buried. ${ }^{71}$ Finally, there was a 're-enchantment' of Chinese medicine in the 1980s that saw the reinsertion of talk of qi, 'Five Elements' and systematic correspondences (which Needham dismissed as 'medieval') into statesponsored textbooks and everyday practice. This was a response to the vicissitudes of the global medical marketplace, in which 'post-war, postmodern' Western consumers 'disillusioned with ... the limitations and harmfulness of Western medicine' demanded a holistic therapy with an alternative cosmology that did not need to be explained by or integrated with biomedicine. ${ }^{72}$ The default condition of Chinese medicine in China now seems to be varying degrees of 'bilingualism without integration', as observed by anthropologists Mei Zhan and Eric Karchmer, whereby Chinese doctors could switch from one set of terminologies or procedures to another (Chinese to Western and back) depending on the clinical encounter, pedagogical situation or polemical moment. ${ }^{73}$

If Joseph Needham admired Chinese medicine because of the promises that acupuncture appeared to hold, his engagement with South Asian medical traditions was by contrast very limited. I would argue that it was precisely because Ayurvedic or Unani-Islamic systems of medicine did not, for Needham, offer anything as distinctive and exciting as acupuncture that could contribute to the 'fusion' of East and West in order to make an 'oecumenical medicine'. In a 1966 lecture at the Wellcome Historical Museum and Library, Needham and Lu Gwei-Djen quite flatly stated that, even though 'Ayurvedic medicine ... [had] some similarity with Chinese traditional medicine', it was 'less original and peculiar in its methods' - there was no further commentary on 'originality' and 'peculiarity'. ${ }^{74}$ Needham did, however, display a keen interest in the history and twentiethcentury laboratory investigations of Indian yoga exercises, although he would finally conclude that yoga was not as superior as the Chinese tradition of inner alchemy (neidan), self-cultivation (yangsheng) and the gymnastics associated with them. ${ }^{75}$ That

71 Taylor, op. cit. (46), pp.138-140; Elisabeth Hsu, 'Innovations in acumoxa: acupuncture analgesia, scalp and ear acupuncture in the People's Republic of China', Social Science and Medicine (1996) 52, pp. 421-430; Eric Hayot, The Hypothetical Mandarin: Sympathy, Modernity, and Chinese Pain, Oxford: Oxford University Press, pp. 207-245, provides a reading of the photographs of acupuncture anaesthesia.

72 Taylor, op. cit. (46), p. 140. See also Linda L. Barnes, 'Multiple meanings of Chinese healing in the United States', in Linda L. Barnes and Susan S. Sered (eds.), Religion and Healing in America, Oxford: Oxford University Press, 2005, pp. 307-332; Kim Taylor, 'Divergent interests and cultivated misunderstandings: the influence of the West on modern Chinese medicine', Social History of Medicine (2004) 17, pp. 93-111.

73 Zhan, op. cit. (67), pp. 119-144; Eric Karchmer, 'Chinese medicine in action: on the postcoloniality of medical practice in China', Medical Anthropology (2010) 29, pp. 1-27.

74 Joseph Needham and Lu Gwei-Djen, 'Medicine and Chinese culture', in Needham, Clerks and Craftsmen in China and in the West, op. cit. (32), pp. 263-293, 289. This was presented at the Symposium on Medicine and Culture at the Wellcome Historical Museum and Library in London.

75 Generally speaking, there were two branches of alchemy in early China. 'Outer alchemy' (waidan) involved the concoction of the elixir of life in a cauldron using various metallic and mineral ingredients; the 
lengthy and eclectic discussion could be found in SCC volume 5, Chemistry and Chemical Technology, part 5, Spagyrical Discovery and Invention: Physiological Alchemy. ${ }^{76}$

Needham began by briefly explaining the meaning of the word 'yoga':

both self-discipline and union, discipline to remove the individual aspirant from the 'red dust' bung chhen, (as we should say in China) of the worldly turmoil of the world, and to lead to mystical union of the individual with the universe, a union which would liberate him or her from the dominion of events and history, an attainment of 'eternal life in the midst of time'. [Yoga] thus became one of the six 'orthodox' Hindu systems ... and played a part in every form of Indian culture wherever it penetrated. ${ }^{77}$

Drawing on a diverse body of scholarship, including the work of sanskritist Surendranath Dasgupta (1887-1952), historian of religion Mircea Eliade (19071986), indologist Jean Filliozat (1906-1982) and philosopher Paul Masson-Oursel (1882-1956), Needham then outlined the history of the three 'great movements' of a yogistic character in Indian culture. ${ }^{78}$ The first wave was during the second century BCE, when the first three chapters of the still extant Yoga Sutras of Patanjali were compiled. The text prescribed the eight principal elements of yoga: yama and niyama (a moral code which involved abstention from harming living creatures, rejection of avarice, abstinence from generative sex, peace of mind under all circumstances, avoidance of any particular attachments); asana (which involved gymnastics and often contortionist postures for mental concentration and physical conditioning); paranayama (breathing control); pratyahara (withdrawal of the senses); dharana (concentration or 'single focus'); dhyana (meditation); samadhi (being out of physical consciousness or in a trance). The second wave of the yoga movement was tantrism, which began to flourish from around the fourth to sixth centuries CE. In tantrism, 'great weight was laid on the importance of sex in the scheme of things; the real cosmic energy was feminine (creative as in the bearing of children and the inspiring of men), embodied in the [shakti] or consort of every one of the gods' ${ }^{79}$ Moreover, tantrism rejected the extreme ascetic or self-torture practices of high antiquity. Iconography, spells, charms and talismans were all crucial in this movement. Yoga's third wave was Hathayoga, starting between the ninth and twelfth centuries CE, in which

elixir of life was then ingested. 'Inner alchemy' (neidan) developed later, and the human body itself was seen as a reaction vessel or chamber, and the elixir of life was manufactured from within through the manipulation of bodily fluids and vital essences (meditation, breathing and gymnastic exercises, sexual techniques, dietary regimens and prohibitions, and so forth). Needham would equate 'outer alchemy' with 'Chinese protochemistry' or 'inorganic laboratory alchemy', and 'inner alchemy' with 'Chinese proto-biochemistry' or 'proto-physiology'.

76 Joseph Needham, Science and Civilisation in China, vol. 5: Chemistry and Chemical Technology, part 5: Spagyrical Discovery and Invention: Physiological Alchemy, with the collaboration of Lu Gwei-Djen, Cambridge: Cambridge University Press, 1983, pp. 257-288.

77 Needham, op. cit. (76), p. 259.

78 Needham, op. cit. (76), pp. 257-261.

79 Needham, op. cit. (76), p. 260. 
[t]he importance of the human body as the real seat of gods was strongly emphasised ... Holiness was only realisable physically as well as mystically; and so for the first time there occurred a shift from the classical idea of deliverance here and now from the life within time and space (jivan-mukti), to the idea of deliverance from the death of the body. ${ }^{80}$

Needham then pointed towards the general characteristics of the yogistic systems, such as 'contrariness' (attempts to go contrary to all normal human inclinations such as making bodily fluids flow 'inwards' and not 'outwards'), magic and supernatural powers (invisibility, invulnerability and so forth attributed to the yoga masters), transcendence from all dualities and the achievement of great unity, and the idea of the human body as microcosm. ${ }^{81}$ Following from this, Needham analysed each of the eight principal elements of yoga in detail, while identifying the similarities and differences with Chinese philosophy and Daoist practices for the cultivation of health. ${ }^{82}$ So far, there was nothing particularly controversial about Needham's summaries. Halfway through the section on yoga, the tone shifted as Needham launched into the verification of yoga practices via modern physiological methods. He cited the work of French cardiologists Charles Laubry (1872-1960) and Thérèse Brosse (1902-1991); in 1936 Brosse conducted extensive field studies in India and monitored the respiration rate and the heart activity of yogis via the use of electrocardiograms (ECGs). Laubry and Brosse found that there were 'all kinds of willed modifications of respiratory rate, accelerations of heart rate up to 150 beats per minute'. ${ }^{83}$ Some practitioners appeared to be able to stop their hearts voluntarily; they argued that yoga exercises could lead to voluntary mastery over involuntary muscles and vegetative muscles. Another piece of research that Needham tapped into was carried out by Kovoor Thomas (K.T.) Behanan (19021960), an Indian philosopher and psychologist who examined the physiological effects of yoga as a Sterling Fellow at Yale University's Graduate Department of Psychology in the early 1930s, under the direction of Walter Richard Miles (1885-1978). In 1937 Behanan published Yoga: Its Scientific Basis, concluding that, through laboratory investigations on the oxygen consumption and muscular control of yogis as well as mental testing, yoga offered a 'practical programme for the attainment of what any judicious person would admit is an enviable frame of mind - one that is not easily perturbed by emotional conflicts'. ${ }^{84}$ Needham also appealed to later research on yoga, 'hibernation' and reduced metabolism from the 1950s and 1960s by Bal Krishnan Anand (19172007) at the All India Institute of Medical Sciences, Basu Kumar Bagchi (1895-1977)

80 Needham, op. cit. (76), p. 261.

81 Needham, op. cit. (76), pp. 261-262.

82 Needham, op. cit. (76), pp. 263-270.

83 Needham, op. cit. (76), p. 271; Charles Laubry and Thérèse Brosse, 'Documents recueillis aux Indes sur les “Yoguis" par l'enregistrement simultané du pouls, de la respiration et de l'electrocardiogramme', Presse médicale (1936) 44, pp. 1601-1604; Thérèse Brosse, Etudes instrumentals des techniques du Yoga: Expérimentation psychosomatique, with an introduction 'La nature du Yoga dans sa tradition' by Jean Filliozat, Paris: Ecole française d'extrême-orient, 1963.

84 Kovoor T. Behanan, Yoga: Its Scientific Basis, New York: Macmillan, 1937, pp. 246-247. 
at University of Michigan Medical Centre, and Marion Augustus Wenger (1907-1982) at the University of California, Los Angeles. ${ }^{85}$

Even though Needham's inquiries into yoga convinced him of the sophistication of the tantric and Hathayoga systems, and the various scientific research projects demonstrated for him 'the reality of many of the effects produced in yogistic physiological practices', he would finally declare that Chinese macrobiotic regimens were superior because they showed 'greater sobriety and a much more materialist tendency'. ${ }^{86}$ The Chinese gymnastic exercises never seemed to involve the 'extreme contortionist asana of their yogistic colleagues', the Chinese were not as 'antinomian' or 'other-worldly' as their Indian counterparts and did not try to go contrary to all natural human desire. ${ }^{87}$ Most importantly, for Needham, Chinese macrobiotics was less 'idealist' and more 'proto-scientific' than yoga, as it aimed to

accomplish nothing less than the reversal of the ageing process, to return to the perfection of infancy, the time before growth has ceased, the time when (as we now know) the biochemical changes accompanying senescence have hardly begun to take place ... [The Daoist adepts were] engaged in a quest essentially scientific, the re-mounting of the growth-rate curve, the reestablishment of the enzymic and hormonal situation of the organism at the beginning of life, the re-gaining, restoring and maintaining of the faultless chemical and physiological constitution with which every child is endowed. ${ }^{88}$

Once again, China trumped India. But there was a bemusing contradiction here: Indian civilization was first of all being accused of being too familiar and similar to European civilization, while things Chinese (the exemplar being acupuncture) inspired the 'deepest love' and 'profoundest desire' because they appeared for Needham so otherly and peculiar and original and ingenious. Yet, with the case of Indian yoga, it was regarded as less 'materialist' and thus inferior vis-à-vis Chinese macrobiotics because the Chinese programme was more 'essentially scientific'. But, paradoxically, would that not imply that the Chinese were after all more like the Europeans, i.e. Chinese science was 'less unfamiliar' compared to Indian science? To this I can only offer a quip on 'love': perhaps, I love someone (or some 'thing') not because it happens to gather all (or most) of the properties that are worthy of love, but because I believe it contains a 'kernel' such that all (or most) of its properties appear worthy of love. And that

85 Needham, op. cit. (76), p. 271; B.K. Anand and G.S. Chinna, 'Investigations of Yogis claiming to stop their heart beats', Indian Journal of Medical Research (1961) 49, pp. 90-94; B.K. Anand, G.S. Chinna and Baldev Singh, 'Studies on Shri Ramanand Yogi during his stay in air-tight box', Indian Journal of Medical Research (1961) 49, pp. 82-89; B.K. Bagchi and M.A. Wenger, 'Electrophysiological correlates of some Yogi exercises', Electroencephalography and Clinical Neurophysiology (1957) 7, pp. 132-149. More generally see Joseph S. Alter, Yoga in Modern India: The Body between Science and Philosophy, Princeton: Princeton University Press, 2004, pp. 73-108; William J. Broad, The Science of Yoga: The Risks and Rewards, New York: Simon and Schuster, 2012.

86 Needham, op. cit. (76), pp. 272-273, 287.

87 Needham, op. cit. (76), p. 287. More recent scholarship, however, has suggested that postural yoga (asana) may have been a more recent product that owes a greater debt to modern Indian nationalism and to the bodybuilding and gymnastic cultures of Europe and America than it does to any ancient tradition. See Mark Singleton, Yoga Body: The Origins of Modern Posture Practice, Oxford: Oxford University Press, 2010.

88 Needham, op. cit. (76), p. 288. 
kernel is the 'truth', the answers to my dilemmas: in psychoanalytic terms it is identity, the question of who I am. ${ }^{89}$ To love China is to believe that by loving it, it will provide solutions to one's fundamental questions (philosophical, historical, cultural, scientific ...).

\section{The transmission of golden juices East and West}

In the mid-1960s and the 1970s, Needham was deeply immersed in the history of Chinese alchemy, resulting in four volumes of SCC on the subject. ${ }^{90}$ As I argued elsewhere, he was preoccupied with Chinese alchemy for a number of reasons. He believed that the self-cultivation and bodily techniques associated with Chinese 'inner alchemy' could be refurbished for the consumption of men and women living in a modern, alienated world. ${ }^{91}$ Another reason was the problem of transmission of knowledge; particularly, did anything flow from China westwards to impact the development of Western science? Needham was convinced that there were Chinese scientific discoveries that went into the making of the Scientific Revolution, and for him alchemy emerged as a promising candidate. India, alongside Inner Asia and the Middle East, appeared in his historiography as nodes in that westward flow. In a 1966 lecture delivered at Beirut, Needham offered a highly idiosyncratic method of establishing transmission between two distant sites:

We often know very little of how transmission took place, but [as] in all [other] fields of science and technology, the onus of proof lies upon those who wish to maintain fully independent invention, and the longer the period elapsing between the successive appearances of a discovery or invention in [the] two or more cultures concerned, the heavier that onus generally is. ${ }^{92}$

89 A reading of love from Slavoj Žižek, The Parallax View, Cambridge, MA: MIT Press, 2009, p. 355. Of course, the most widely known biography of Needham, by Simon Winchester, is entitled The Man Who Loved China: The Fantastic Story of the Eccentric Scientist Who Unlocked the Mysteries of the Middle Kingdom, New York: HarperCollins, 2008. In the United Kingdom, the title is Bomb, Book and Compass: Joseph Needham and the Great Secrets of China, London: Viking, 2008. As I suggested before, in Rocha, 'The way of sex', op. cit. (14), p. 622 n. 109, Winchester reduced Needham to a caricature: an eccentric ChristianDaoist-communist, a free-love practising Cambridge don with a penchant for Morris-dancing and nudism, who fell in love with China via an 'exotic' Chinese woman (Lu Gwei-Djen) and then produced tomes that 'unlocked the mysteries' of China. In other words, 'The Man Who Loved China ... because he fell in love with a Chinese woman'. 'The man who loved China' is an acceptable epithet for Needham, but only if we add a more appropriate second part: 'The man who loved China ... because he thought China could answer his questions'.

90 Joseph Needham, Science and Civilisation in China, vol. 5: Chemistry and Chemical Technology, part 2: Spagyrical Discovery and Invention: Magisteries of Gold and Immortality, with the collaboration of Lu GweiDjen, Cambridge: Cambridge University Press, 1974; Needham, Science and Civilisation in China, vol. 5: Chemistry and Chemical Technology, part 3: Spagyrical Discovery and Invention: Historical Survey, from Cinnabar Elixirs to Synthetic Insulin, with the collaboration of Ho Peng-Yoke and Lu Gwei-Djen, Cambridge: Cambridge University Press, 1976; Needham, Science and Civilisation in China, vol. 5: Chemistry and Chemical Technology, part 4: Spagyrical Discovery and Invention: Apparatus and Theory, with the collaboration of Lu Gwei-Djen, Cambridge: Cambridge University Press, 1983; Needham, op. cit. (76).

91 Rocha, 'The way of sex', op. cit. (14).

92 Joseph Needham, 'China, Europe, and the seas between', in Needham, Clerks and Craftsmen in China and in the West, op. cit. (32), pp. 40-70, 70. Lecture at the International Congress of Maritime History, Beirut, in 1966. 
Needham suggested that 'this principle has run through the whole of the SCC series'. ${ }^{93}$ Where did this principle come from? In 1985, Needham and Lu Gwei-Djen published Trans-Pacific Echoes and Resonances: Listening Once Again. Needham and Lu's unusual book reviews archaeological and anthropological literature on Amerindian people and the circum-Pacific regions. The two scholars concluded that there were occasional visits of Asian peoples to the Western part of the American continent over 2,500 years, probably on sailing rafts or junks blown off course, and traces of Asian influence (however minute) could be discerned from a thorough analysis of patterns or motifs in art, music, language, mythology and folklore. In other words, Needham and Lu subscribed to a version of what was called the 'pre-Columbian trans-oceanic contact theory', whereby people from other continents (Asians in this case) discovered or interacted with Native Americans allegedly well before the Columbus expedition in the fifteenth century. They drew from the work of Alfred L. Kroeber (1876-1960), student of Franz Boas (1858-1942) and professor of anthropology at Berkeley, who studied the Yana Native Americans indigenous to Northern California and the Sierra Nevada. ${ }^{94}$

In the theoretical section of Trans-Pacific Echoes and Resonances, Needham and Lu also concurred with the arguments put forward by Douglas Fraser (1929-1982), professor of art history and archaeology at Columbia, an expert in African and Oceanic art. ${ }^{95}$ Fraser argued that if the 'primitive' art of two cultures shared motifs or styles that were so intricate and complex, then on the balance of probabilities one ought to assume that contact and exchange had happened even if the two cultures were extremely far apart from one another. This species of argumentation was called 'diffusionism', in contrast to 'isolationism' i.e. scholars who rejected the notion that similarities in motifs or styles constituted sufficient evidence of transmission between cultures and who would prefer to argue for independent invention. While Fraser concentrated on art, other diffusionists speculated on contact using 'pattern recognition' to study language, ritual and myths. Diffusionism as a research programme for 'primitive' and ancient cultures was en vogue in the 1960s and moribund by the 1970s; when Needham and Lu published Trans-Pacific Echoes and Resonances in the mid-1980s it appeared seriously anachronistic - though the first volume of perhaps the most controversial diffusionist work, Black Athena: The Afroasiatic Roots of Classical Civilisation by Needham's close friend Martin Bernal (1937-2013), was published in 1987. ${ }^{96}$ Borrowing from the diffusionist

93 Joseph Needham and Lu Gwei-Djen, Trans-Pacific Echoes and Resonances: Listening Once Again, Singapore: World Scientific Publishing, 1985, p. 13.

94 Needham and Lu, op. cit. (93), p. 14. They cite the classic paper by Alfred L. Kroeber, 'Stimulus diffusion', American Anthropologist (1940) 42, pp. 1-20. On Kroeber see Terry L. Jones, Alice A. Storey, Eliszabeth A. Matisoo-Smith and José Miguel Ramírez-Aliaga (eds.), Polynesians in America: PreColumbian Contacts with the New World, Lanham, MD: Rowman AltaMira, 2011.

95 Needham and Lu, op. cit. (93), pp. 7-14; Douglas Fraser, Primitive Art, New York: Doubleday, 1962; Fraser (ed.), The Many Faces of Primitive Art: A Critical Anthology, New York: Prentice-Hall, 1966. On Fraser in general see Ben Burt, World Art: An Introduction to the Art in Artefacts, London: Bloomsbury, 2013, pp. 59-61.

96 Martin Bernal, Black Athena: The Afroasiatic Roots of Classical Civilisation, New Brunswick, NJ: Rutgers University Press, 1987, later published as Black Athena: Afro-Asiatic Roots of Classical Civilization: The Fabrication of Ancient Greece, 1785-1985, vol. 1, New York: Vintage, 1991. Vol. 2 (on 
anthropologists and archaeologists, Needham claimed that, essentially, cross-cultural transmission of science and technology is the default state of affairs. If two scientific theories or artefacts (say, $x$ from Europe and $y$ from China) looked similar then the burden of proof was on those who said that $x$ and $y$ were developed independently of each other. Moreover, Needham argued that the burden of proof became heavier the longer the period of time elapsed between the discovery or invention of $x$ and $y$. Put another way, let us suppose that theory $y$-China and theory $x$-Europe looked similar, and let us also suppose that $y$-China came two centuries before $x$-Europe. From Needham's standpoint then $x$-Europe originated from $y$-China; there had to be transmission from China to Europe.

Of Needham's many historiographical theorizations, Floris Cohen found this account of transmission particularly preposterous. ${ }^{97}$ Needham seemed to allow himself a great degree of freedom to generate enormous claims just from comparative history: if two ideas or artefacts from two different places looked similar, voilà: transmission! If one were to dispute this, then one would have to find the evidence against transmission having taken place. But it would be difficult to visualize what that evidence might actually look like: indeed if no transmission had taken place, then there would be no historical trace. And suppose the unlikely scenario that a manuscript was discovered in which a European natural philosopher explicitly denied that his theory of optics was in any way influenced by similar inquiries in China, what would a historian make of this source? It was upon this problematic foundation that Needham's studies on European and Chinese alchemy proceeded. Immediately after the discussion on yoga in SCC volume 5, part 5, Joseph Needham pondered the question of transmission. He wrote,

The parallel question which comes to mind is what influence ... alchemy had upon the development of science and technology in the West. If one confines attention to specific details of chemical apparatus and operations, the answer would be, for the first case, relatively little, since Western and Arabic alchemy and then chemistry developed more or less in parallel with China in a continuous line of evolution from the proto-chemistry of the Hellenistic period. But if we think of the broader objectives, then the influence was tremendous, for as we argue elsewhere ... no system has the right to be called alchemy until the idea of the elixir of life is present in it; before that all is aurifiction ['gold-faking'] or aurifaction ['goldmaking'] - and the Arabs, who transmitted to Europe the idea of the elixir, were in this profoundly influenced by China. ${ }^{98}$

The Indo-Pakistani scholar Syed Mahdihassan was a crucial influence on Needham; Mahdihassan was another of Needham's long-term correspondents in South Asia. The two men exchanged letters and ideas for thirty-five years, which petered out in the 1980s with the declining health of Mahdihassan and of Dorothy Moyle Needham. ${ }^{99}$ Mahdihassan left a clear trace in Needham's work: in volume 5, part 5, fifty-five of

archaeological and documentary evidence) and vol. 3 (on linguistic evidence) were published in 1991 and 2006 respectively.

97 Cohen, op. cit. (5), p. 436

98 Needham, op. cit. (76), p. 298.

99 NRI Papers, Needham/NRI2/SCC2/222/1-28, twenty-eight bundles of letters dated 1953-1988. Dorothy Moyle Needham's death in 1985 and Joseph's old age meant that around the late 1980s he had ceased regular communication with many colleagues in his extremely wide network. Many letters were 
Mahdihassan's books and articles were cited in the bibliography (more than any other scholar) and in volume 5, part 4, Needham discusses Mahdihassan's historical thesis in close detail. ${ }^{100}$ Mahdihassan was a chemist and historian who obtained his $\mathrm{PhD}$ in zoology from the University of Giessen in 1937. Obtaining his diploma in agricultural sciences from Oxford, Mahdihassan returned to India around the 1940s and worked at the Chemical, Industrial and Pharmaceutical Laboratories (now Cipla) in Mumbai. He became the head of the Biochemical Research Division in the Pakistan Council of Scientific and Industrial Research (PCSIR) in Karachi, where he worked on, among many projects, insect pigments and pest control. Mahdihassan's later work on science and on history of medicine was sponsored by the Hamdard National Foundation, which was deeply invested in modernizing Unani medicine via Western biomedicine as well as promoting the contribution of Islamic culture to Indian civilization. ${ }^{101}$

It was probably around the 1940s that Needham first encountered Mahdihassan's work. Throughout the 1950 s to 1970 s, the two men exchanged letters on the theories in early medieval Chinese alchemy, ancient symbols and colours, the so-called 'Four Directions' and 'Five Elements', mythical creatures like the phoenix and the dragons, traditional Chinese cosmology and divination techniques, and so forth. ${ }^{102}$ They also discussed scholars writing on the history of alchemy and chemistry around the world; Needham advised Mahdihassan on setting up networks in history of science and history of medicine in Pakistan, and on acquiring European journal papers and research materials. ${ }^{103}$ They sent each other work to comment on, for instance Mahdihassan's paper on soma in which he argued that the main ingredient of the Vedic ritual drink (probably with hallucinogenic effects) was Ganoderma lucidum (lingzhi mushroom), the fungus of immortality and an 'elixir of life' described in Han Dynasty texts. ${ }^{104}$ This research culminated in Mahdihassan's monograph in which he revised his thesis, with Needham's input, and argued that Ephedra sinica (mahuang) was the main ingredient of soma. ${ }^{105}$ In turn, Mahdihassan read and critiqued sections of SCC.

The discussion on alchemy between Needham and Mahdihassan orbited around the hypothesis of the 'Chinese impact on European alchemy'. Both men built their case on etymological arguments, and then drew attention to the parallelisms between alchemical symbols and techniques from Europe and Asia: in SCC volume 5, part 4, Needham argued his case over some two hundred pages. ${ }^{106}$ To cut a rather protracted inquiry quite short, Mahdihassan and Needham proposed that the 'chem' part of the word

replied by Gregory Blue, who was then a research associate at Cambridge, with Needham's approval. NRI Papers, Needham/NRI2/SCC2/222/20, 23.

100 Needham, op. cit. (76), pp. 468-469; Needham, part 4, op. cit. (90), pp. 352-356.

101 See biographical timeline in Hakim Mohammad Said (ed.), Essays on Science: Felicitation Volume in Honour of Dr S. Mahdihassan, Karachi: Hamdard Foundation Press, 1987, pp. xiii-xv.

102 NRI Papers, Needham/NRI2/SCC2/222/1, 2, 9, 12, 14, 16.

103 NRI Papers, Needham/NRI2/SCC2/222/4, 5, 7, 8, 17, 24.

104 Syed Mahdihassan, 'The soma of the Aryans and the chih of the Chinese', May and Baker Pharmaceutical Bulletin (1972) 21, p. 30. NRI Papers, Needham/NRI2/SCC2/222/3, 6.

105 Syed Mahdihassan, The History and Natural History of Ephedra as Soma, Islamabad: Pakistan Science Foundation, 1987.

106 Needham, part 4, op. cit. (90), pp. 323-501. 
'alchemy' (Old French alquimie, medieval Latin alchimia, Arabic al-kimia, ancient Greek chemeia or chymeia) ultimately came from middle Chinese kiem-yak, the approximate pronunciation of present-day Mandarin jinye, literally 'golden juices'. ${ }^{107}$ From the etymological explorations, Mahdihassan put forward a 'strong' version of the 'Chinese-impact' hypothesis, namely he suggested that alchemy originated from China. On the other hand, Needham advanced a 'weaker' version whereby European alchemy was really a melting pot of Chinese, Indian, Persian, Arabic, Greek, Roman and Egyptian theories and practices. ${ }^{108}$ Even though the etymological arguments by Mahdihassan and Needham are still occasionally cited, ${ }^{109}$ the consensus among current historians of alchemy is that the Greek term chemeia or chymeia is

probably derived from the word for smelting metals (cheein), [which] had encompassed a variety of metallurgical and chemical techniques by the time it was appropriated by the Arabs in the early Middle Ages. Arabic-speaking authors of course added the definite article al to the transliterated noun kimiya, to arrive at al-kimiya, the linguistic progenitor of the Latin alchymia and its orthographic variants such as alchemia and alchimia. ${ }^{110}$

In fact, Lawrence Principe argues that the Western term 'alchemy' 'might even prove to be a misleading label' for the practices known as waidan and neidan in China, and the 'ahistorical conflation of Chinese and Western alchemy spawned the popular, but erroneous, notion that European alchemists sought an "elixir of immortality". Even though Western alchemists 'did seek medicines that would extend life, the search for earthly immortality through alchemy was a uniquely Chinese goal'. ${ }^{111}$ Similarly, Principe's frequent collaborator William Newman brackets out China in his history of alchemy: neither Principe nor Newman accepts the 'kiem-yak-to-alchemy' argument, and they do not discern deep parallels or meaningful historical linkages between Western and

107 See Syed Mahdihassan, 'The Chinese origin of three cognate words: chemistry, elixir and genii', Journal of the University of Bombay (1951) 20, pp. 107-131; Mahdihassan, 'Alchemy and its Chinese origin as revealed by its etymology, doctrines and symbols', Iqbal Review (1966) 7, pp. 22-58; Mahdihassan, 'Chinese alchemy in the light of its fundamental terms', American Journal of Chinese Medicine (1980) 8, pp. 307-312; Mahdihassan, 'Alchemy, Chinese versus Greek, an etymological approach: a rejoinder', American Journal of Chinese Medicine (1988) 16, pp. 83-86; Needham, part 4, op. cit. (90), pp. 352-356.

108 Later historians of Indian alchemy, such as Vijaya Deshpande, argued that transmission of alchemical ideas might have existed between India and China, but declined to comment on what implication (if any) there was for the development of European alchemy. For example, Vijava Deshpande, 'Mediaeval transmission of alchemical and chemical ideas between India and China', Indian Journal of History of Science (1987) 22, pp. 15-28. Deshpande wrote to Needham in late 1983 and early 1984 (with Needham's assistant Gregory Blue replying), and as far as I can gather there was no meaningful conversation between the two scholars. See NRI Papers, Needham/NRI2/SCC2/229/114 and Needham/NRI2/SCC2/209/19.

109 David Gordon White, The Alchemical Body: Siddha Traditions in Mediaeval India, Chicago: The University of Chicago Press, 1996, p. 377 n. 62; P.G. Maxwell-Stuart, The Chemical Choir: A History of Alchemy, London: Continuum, 2008, p. 1; Aaron Cheak, 'Introduction to part one: circumambulating the alchemical mysterium', in Cheak (ed.), Alchemical Traditions: From Antiquity to the Avant-Garde, Melbourne: Numen Books, pp. 18-43, 24-25.

110 William R. Newman and Lawrence M. Principe, 'Alchemy vs. chemistry: the etymological origins of a historiographic mistake', Early Science and Medicine (1998) 3, pp. 32-65, 38.

111 Lawrence M. Principe, The Secrets of Alchemy, Chicago: The University of Chicago Press, 2012, pp. 5-6, original emphasis. 
Chinese alchemy. ${ }^{112}$ Needham himself admitted that, on the level of apparatus and operations, there was relatively little, if any, influence. But for Needham it would seem too much of a coincidence for two different cultures to develop independently the preoccupation with gold, and the transformation of base substances into elixirs and panaceas. Needham's commitment to a form of diffusionism and connectedness, as well as his desire to discover seeds of the East in the European Scientific Revolution, pushed him towards an account of contact and transmission between China and Europe that would now appear unsustainable and obsolete.

\section{Conclusion: do we believe in life after love?}

Where do we go from here? From a deflationary view, one can sum up this paper as presenting Joseph Needham's idiosyncratic historiography. We have a sinophile - a 'man who loved China', to use Simon Winchester's epithet - who was interested in demonstrating China's priority in developing numerous scientific discoveries and technological inventions via the method of 'grand titration'. He accorded a unique status to traditional healing in China, particularly acupuncture, as he believed that acupuncture could 'fuse' with Western biomedicine to become an 'oecumenical medicine'. However, Needham was also a 'man who did not love India that much', and did not see anything within Indian medicine that had the potential for rejuvenation and refurbishment for present use. His reasoning for his ranking of Chinese versus Indian civilization was confusing at best: sometimes Indian culture was too familiar while Chinese culture was more otherly; sometimes Indian thought was too transcendental and 'other-worldly' while Chinese philosophy was supposedly more materialist and rational; sometimes Indian science was 'not very original' (and the criteria for 'originality' were never spelled out) while Chinese science was more 'proto-scientific'. An uncharitable critic might brand some of Needham's preconceptions of China and India as 'orientalist'. Finally, an outmoded framework of diffusionism that too readily attributed cross-cultural contact and exchange based on parallelisms, as well as an investment in establishing Chinese contributions to the Scientific Revolution, led Needham into a labyrinthine investigation into the history of alchemy in which India appeared as an intersection or junction of transmission of scientific knowledge from East to West. Given the problems in Needham's historiography, and the decline of large-scale histories in general in favour of local case studies, it is perhaps unsurprising that SCC is often simply mined for facts and references by scholars who would rarely engage with its narrative thrust or style of argumentation.

Could one distil some useful questions beyond this 'negative' reading? First, let us think about the asymmetry in the writing of the history of medicine versus the history of science. Lu and Needham's Celestial Lancets was conceived at the historical juncture when the Chinese party state was pushing for the integration of Chinese and Western medicines and strongly promoted scientized acupuncture as an indigenous, 'folk

112 William R. Newman, Promethean Ambitions: Alchemy and the Quest to Perfect Nature, Chicago: The University of Chicago Press, 2005, p. 25. 
wisdom' that enshrined China's cultural genius. Postcolonial India was likewise reinventing and repackaging Ayurveda or Unani medicine, conducting laboratory experiments to prove its physiological effects and macrobiotic benefits, or advertising it as embodying an alternative, holistic system of healing. It was also a time when, in Europe and North America, the postmodern mistrust of science facilitated the global proliferation of so-called 'complementary and alternative medicines'. The writing of history of non-Western science versus non-Western medicine continues to be inextricably entwined with these politics, if not to reproduce those power dynamics. Whereas non-Western medicine is often seen as crucial insofar as it may bring to light new conceptualizations of health or even new therapeutic possibilities, non-Western science does not attract a similar level of engagement. Non-Western science is neither generally regarded as a precursor to any modern scientific discipline, nor seen as capable of generating any new useful knowledge let alone mounting serious epistemological challenges. And the history of non-Western science in the twentieth century can often boil down to a form of Rezeptionsgeschichte that highlights native agency in the appropriation of Western science for nation-building projects. Joseph Needham's 'oecumenism' appeared to animate an eccentric historiography, a historiography that privileged Chinese medicine because the 'fusion' between Western medicine and Chinese medicine had not yet taken place (to produce an 'oecumenical medicine'), but foreclosed Chinese science because the 'fusion' between (say) Western astronomy and Chinese astronomy had allegedly already taken place in the seventeenth century. However, there is a political vision, a spirit of openness, an ethical imperative embedded in Needham's idea of 'oecumenism' that may be worth inheriting: that modern science and medicine (as we currently know them) are not a complete and settled project; that they may not have a monopoly on 'truth'; that there is still the possibility that non-Western cultures can revise our ways of knowing and seeing; that doing the history of science and medicine in those nonWestern cultures (China, India ...) may help towards building a pluralistic science in the future that fully acknowledges the complexity of nature and reality and that encompasses the partial perspectives from different classes, genders, ethnicities and cultures.

Second, if Needham's diffusionist framework, which sets a criterion for establishing cross-cultural contact and exchange, is unacceptable to most empirical historians, there is nevertheless a commitment to transmissions that has enjoyed renewed vitality. The recent work of Kapil Raj is illuminating in this regard. ${ }^{113}$ Raj suggests that the commerce-driven circulation of people, goods and ideas across terrestrial and maritime trade routes was itself the locus of scientific and technological innovation. Raj postulates the

113 Kapil Raj, Relocating Modern Science: Circulation and the Construction of Knowledge in South Asia and Europe, 1650-1900, Basingstoke: Palgrave Macmillan, 2007; Raj, 'Mapping knowledge go-betweens in Calcutta, 1770-1820', in Simon Schaffer, Lissa Roberts, Kapil Raj and James Delbourgo (eds.), The Brokered World: Go-betweens and Global Intelligence, 1770-1820, Sagamore Beach, MA: Science History Publications, 2009, pp. 105-150; Raj, 'The historical anatomy of a contact zone: Calcutta in the eighteenth century', Indian Economic and Social History Review (2011) 48, pp. 55-82; Raj, 'Beyond postcolonialism ... and postpostivism: circulation and the global history of science', Isis (2013) 104, pp. 337-347; Raj, 'Rescuing science from civilisation: on Joseph Needham's “Asiatic mode of (knowledge) production"', in Arun Bala and Prasenjit Duara (eds.), The Bright Dark Ages: Comparative and Connective Perspectives, Leiden: Brill, forthcoming. 
existence of an 'Asiatic mode of knowledge production' that drew on resources distributed across what he called 'contact zones' in Asia, such that when Europeans sailed to the Indian Ocean by the sixteenth century they were entering an established network of production of practical knowledge on natural history, map-making, terrestrial surveying, linguistics, jurisprudence and governance, and other domains. It was these continuous encounters, interactions and appropriations that enabled the accumulation of knowledge in Europe in the seventeenth and eighteenth centuries; Raj therefore 'relocates' modern science and puts forward a global account of science that simultaneously avoids Eurocentrism and the kind of sinocentrism that Needham occasionally slips into in SCC. The key lesson from Needham and post-Needhamians is that we should temper the impulse to situate science within a confined geopolitical region (Europe, Asia, a particular empire or nation state) while bracketing out others, and instead look for the intersections and connections without which science is impossible.

Finally, let us return to Joseph Needham's sinophilia. From his outlook, China was indeed the privileged channel through which to examine the basic dilemmas of modernity, and more often than not, China also emerged as providing the most promising solutions. Indeed I tend to see Needham as being preoccupied with a host of 'Needham questions', as opposed to just one 'Needham question' (i.e. the non-emergence of modern science in China). These questions include, among many others: the philosophical (e.g. finding a way out of the dualities such as subject versus object), the sociopolitical (e.g. the organization of the social world such that everyone can fulfil their potential) and the ethical (e.g. coming to consensus on a universal set of values based on diverse insights of cultures around the world). These questions animated generations of twentieth-century intellectuals around the world, and inspired an intense love for China in Needham that still needs to be carefully historicized. In turn, of course, we should interrogate the functions that 'China', 'India' or 'Europe' have in our work, how we see each as providing answers (or not) to our larger questions about science and history, and how our beliefs on what is primary or secondary to our historiography may be driven by preconceptions and imaginations that are hostages to our own mode of production. Taking Needham's scholarship as a provocation to deconstruction, perhaps historians of science and medicine could start reflecting on these questions:

When we are doing the history of a particular set of scientific knowledge in Europe, do we feel the need to take into account the history of a similar set of knowledge in China or India?

If we feel we can bracket out China or India, what are the reasons? Is it simply because of the specialization and necessary 'compartmentalization' in academic research, i.e. 'we simply cannot do everything'? Is it because of the persistent tendency in current history of science to embrace the smaller case study and to eschew larger arcs of circulation? Or is it because, deep down, we feel that European science has 'won' (and has produced 'modernity', 'capitalism' and so forth), and so China and India are at best 'appendices' to the history of 'real science'? Or is it because we have decided that no grounds of comparison exist between Chinese, Indian and European sciences, that their histories have to be written on their own terms? What are the 
criteria for establishing similarities and differences, translatability and incommensurability? How do we decide if something is 'beyond the scope', 'out of bounds', 'not relevant to the present inquiry'? Is it because we have decided that comparative histories do not generate new insights? And how can comparative histories produce useful knowledge?

When we are doing the history of Chinese and Indian science, what is it that we are trying to accomplish? What is driving our research? Is it gaining historical knowledge for the sake of it? Or are we simply out to satisfy some sort of 'ideological commitment' to fair representation, i.e. 'China and India had science too'? Are we simply doing 'credit attribution', i.e. 'there has to be a global history of science that accounts for Chinese and Indian domains of knowledge'? Is it attempting to uncover episodes of cross-cultural encounter? If some scholars in our field insist that knowledge in the history of European science may enhance or even radically transform the current practice of science, is it possible that knowledge in the history of Chinese and Indian science may do the same?

And if we feel that Chinese and Indian science could have no contribution to modern science, why is this case? What about the history of Chinese and Indian medicine why is it that it is 'easier' to see that doing the history of non-Western medical systems could enrich the practice of medicine? Finally, what do 'China', 'India' or 'Europe' stand for in our work? Is it really permissible, or possible, to label one culture more 'materialist' or less 'mystical' than another, to call one more 'utilitarian' and the other less 'pragmatic'? From what sort of sources, on what sort of basis, could one make these generalizations, essentialisms and dichotomies? Even if we think we are not making these generalizations, essentialisms and dichotomies, are they nevertheless furnishing the way that we think about the histories of science, medicine and technology? To think through these questions is to think through our pride and prejudice, the 'deepest love' and 'profoundest desire' that we have for our subjects of study. 